Uploaded : December 2020

Accepted : January 2021

Published : June 2021

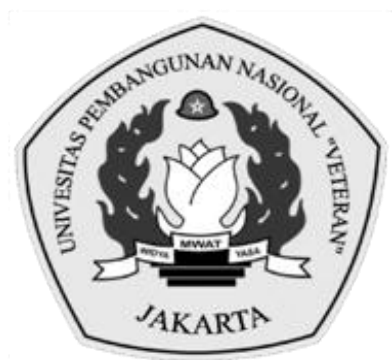

\title{
IS PERFORMANCE-BASED BUDGETING ONLY A MIRAGE?
}

\author{
Rizky Firmansyah \\ rizky.firmansyah.fe@um.ac.id \\ Universitas Negeri Malang, Indonesia
}

\begin{abstract}
This paper aims to explain the implementation of performance-based budgeting. Bureaucratic reform still becomes an important issue in the government area, especially in developing countries, including Indonesia. One part in bureaucratic reform is the change in the government budgeting system. In many countries, this case seems to be imposed, thus the implementation is inappropriate to its true concept. Critical theories become paradigm used in this paper. Critical theory of Habermas was selected as methodology in achieving the objectives of this paper because Habermas's thought is very suitable to the issue raised in this paper, which is consensus path that replaces revolution path as offered by Marx. The importance of interaction emphasized on Habermas's thought becomes basic of analysis due to the interaction or communication based on norm, inter-subjective, demanding role internalization, demanding maintenance of social institution, and action in order to achieve understanding. Performance-based budgeting that should become a solution in achieving people's welfare is still not optimally implemented yet. Physically, the resulted budget has been in performance-based budgeting; however, in fact, indicators of budgeting benefit to the fulfillment of public service are still ignored. The incremental system, planning that is not based on performance, budget inefficiency to the useless expenditure for public, high political interference, also less budgeting control keep involved in regional budgeting in Indonesia. Contradiction between politics and budgeting culture that implemented recently is obstacle for maximal implementation of performance-based budgeting system. There are many research opportunities that can be followed up from this paper such as study about budgeting culture using ethnography perspective and in-depth research about philosophical aspect from performance-based budgeting ideology with state ideology.
\end{abstract}

Keywords: Performance-Based Budgeting; Bureaucratic Reform.

\begin{abstract}
Abstrak
Penelitian ini bertujuan untuk menjelaskan implementasi penganggaran berbasis kinerja. Reformasi birokrasi masih menjadi isu penting di lingkungan pemerintahan, terutama di negara berkembang, termasuk Indonesia. Salah satu bagian dalam reformasi birokrasi adalah perubahan sistem penganggaran pemerintah. Di banyak negara, kasus ini seolah dipaksakan, sehingga implementasinya tidak sesuai dengan konsep aslinya. Teori kritis menjadi paradigma yang digunakan dalam makalah ini. Teori kritis Habermas dipilih sebagai metodologi dalam mencapai tujuan penelitian ini karena pemikiran Habermas sangat sesuai dengan isu yang diangkat dalam makalah ini, yaitu jalur konsensus yang menggantikan jalur revolusi seperti yang ditawarkan oleh Marx. Pentingnya interaksi yang ditekankan pada pemikiran Habermas menjadi dasar analisis karena interaksi atau komunikasi berdasarkan norma, antar subyektif, menuntut internalisasi peran, menuntut pemeliharaan pranata sosial, dan tindakan untuk mencapai pemahaman. Penganggaran berbasis kinerja yang semestinya menjadi solusi dalam mewujudkan kesejahteraan rakyat masih belum terlaksana secara optimal.
\end{abstract}


Secara fisik, anggaran yang dihasilkan adalah anggaran berbasis kinerja. Namun pada kenyataannya, indikator manfaat penganggaran terhadap pemenuhan pelayanan publik masih terabaikan. Sistem incremental, perencanaan yang tidak didasarkan pada kinerja, inefisiensi anggaran hingga pengeluaran yang tidak berguna bagi publik, campur tangan politik yang tinggi, serta pengendalian anggaran yang kurang tetap terlibat dalam penganggaran daerah di Indonesia. Kontradiksi antara politik dan budaya penganggaran yang diterapkan akhir-akhir ini menjadi kendala bagi penerapan sistem penganggaran berbasis kinerja secara maksimal. Banyak peluang penelitian yang dapat ditindaklanjuti dari makalah ini seperti kajian tentang budaya penganggaran dengan perspektif etnografi dan penelitian mendalam tentang aspek filosofis dari ideologi penganggaran berbasis kinerja dengan ideologi negara.

Kata Kunci: Penganggaran Berbasis Kinerja; Reformasi Birokrasi.

\section{INTRODUCTION}

The rise of Performance-Based Budgeting is one of passion driver for regional government in conducting change of budgeting allocation in the region. Indeed, with this performance-based budgeting, the government should conduct performance analysis that will be achieved in the budgeting plan. It can be a solution for developing countries because the implementation of that system will be able to push the government to be truly allocating budget for the fulfillment of people needs. Why is it so? Because in previous perspective, organization of public sector mostly described as unable to handle tasks, too heavy, very powerful, hierarchy, related to the strict rules, inefficient, lazy, incompetent, wasteful, unaccountable, inhuman, focus on self needs, irresponsible, and ignoring outcomes and results (Barzelay, 1992; Shergold, 1997; Gruening, 2001).

Performance-based budgeting derived from New Public Management (NPM) perspective that considered as one bureaucratic paradigm developed from Old Public Administration model. The emphasizing of NPM in its appearance is privatization, employment contract, decentralization, service payment, partnership, management based on result and customer orientation (Gow and Dufour, 2000). NPM has affected process of change in public sector organization comprehensively almost around the world, including Indonesia.

Problems occurred in the implementation of performance-based budgeting include the whole complex aspects. Budgeting becomes part of government performance improvement, which means that budgeting should be truly budgeted based on needs and results, or performance wanted to be achieved and not merely based on interest. As mentioned by Robinson and Last (2009) that performancebased budgeting aims to improve efficiency and effectiveness of public expenditure by relating funding in public sector organization with results of achieved performance using performance information systematically. If it has been established by achievement (performance) that want to be achieved, then it will be calculated by funding needed to result targeted outcome as with performance plan.

The evaluation result of Government Performance Accountability (AKIPAkuntabilitas Kinerja Pemerintah) in 2018 conducted by Ministry of State Apparatus Empowerment and Bureaucratic Reform (KEMENPAN-RB) showed that $50 \%$ from total regencies/cities in Indonesia reported a score of below 50 or in CC category (menpan.go.id, 2019). This has raised many questions about the budget 
allocated each year (annually). On the website of KEMENPAN-RB, it explains that AKIP is indicator of performance to assess the extent of public sector efficiency in utilising the allocated budget. AKIP score shows the level of accountability over outcome to the budget utilization in realizing result-oriented government. It means that AKIP score under 50 gained by $50 \%$ regencies/cities in Indonesia is interesting phenomena.

The budgeting process that has occurred so far is still using the old patterns, namely being dominated by the executive and legislative branches, while community involvement, especially women, is still very minimal, even nonexistent. (Pradnya, 2020; Susetiawan et al., 2018). The implementation of performance-based budgets does not always affect the accountability of agency performance, for example, Muaro Jambi district government agencies whose accountability performance has not changed after implementing performancebased budgets (Utami et al., 2016).

Thus, the problem of this research is how the implementation of performance-based budgeting is. This paper attempts to explore the effectiveness of the implementation of performance-based budgeting. In the next section, this paper explains about New Public Management and performance-based budgeting in the frame of public policy. The explanation will be able to support understanding of relationship between bureaucratic reform and government responsibility to provide quality service in line with the public needs. Subsequently, this paper outlined paradigm and analysis used for the study. This is followed by result and discussion. Last section highlighted conclusion and recommendation for the next research.

\section{LITERATURE REVIEW}

\section{New Public Management}

One of reforms conducted by government is governance change from old Public Administration (OPA) to New Public Management (NPM). In the development, NPM considered as liberation, which is an effort to liberate public management from conservatism of classical administration trap by involving principles of private sector to public sector (Golembiewski, 2003: 133). The more interesting thing is that NPM seen as collection of ideas and practices attempted to use private and business sector approach into public sector (Denhardt, and Denhardt, 2003). Osborne and Gaebler (2003) in the book of Reinventing Government emphasizes the effort to transform entrepreneurship spirit, because in the period where public resource is getting rare, the government should be changed from bureaucratic model to entrepreneurial model. In line with this case, Muhammad (2008) also argued that:

"The government management implements NPM idea is heavily oriented to the entrepreneurship soul and spirit, then New Public Management in the government body called as entrepreneurship management."

It can be stated that the realization of NPM concept in public bureaucracy should be accompanied by the improvement of productivity and determination of 
public service alternatives based on economic perspective. Public manager, in this case is regional leaders, should be encouraged to improve and realize public accountability to the customers (people/public), improve performance, restructure public bureaucracy institutions, formulate organization mission, conduct flow process and bureaucratic procedure, and conduct decentralization in the process of policymaking.

NPM emphasizes control over output on government policy, authority decentralization, introduction to the basic of market quasi mechanism, and customer-oriented service. Lynn (2006) concluded perspective about NPM into three dimensions: structure and process, craft, institutionalized values. As structure and process, NPM is formalization of managerial discretion. As craft, NPM is a concern to make decision and outcomes as well as personal skills needed to present specific role of managerial effectively. As value, NPM includes values over control of formal structure such as responsibility, professionality, and democracy.

\section{Performance-Based Budgeting in the Frame of Public Policy}

In principle, the success of public policy implementation depends on the implementation of performance-based budgeting and also individual behavior involved in the budgeting process. Public policy talks about people (public), adopted values, needs, and things can be chosen as well as their choices. Budgeting, which is type of public policy, has large effect to the human behavior. It is crucial in the budgeting process, employee's behavior should be carefully reviewed and considered to achieve the goal. Rahayu, et al., (2007) found that resistant behavior of unwillingness from state apparatus to the change of budgeting policy mostly occurred in the government. It needs to be concerned, that, in fact, the budgeting actors not really pay attention on the change of policy. Whereas public policy that has been established should be aimed to fulfill people's needs and welfare.

Bromley (1989) explained about public policy in hierarchy that divided into three levels: policy level, organization level, and operational level. Policy level is level of national policy making, which is law instrument and high state institution. In the next level, which is organization level, is level of policy making formulated by executive institution of technical institutional arrangement such as Government Regulation, President Decision, and Regulation of the Minister, also government development program including provision of program funding. Operational level is level of public policy in which the personnel conduct implementation to the policy that been established by policy level and organizational level such as government household. In those various public policy levels, policy evaluation conducted in each policy level through problem formulation related to the regulations (institutional arrangement) with consistency and coherence among policies.

It is then developed and creates the thought that in public policy level, including regional budgeting, problem about perception to the various public policy instruments is fundamental problem that should be concerned in its implementation. Bromley (1989) outlined that tendency of interaction pattern from all stakeholders involved in operational level has certain perception, assumption, and description about the implemented policy. The perception, 
assumption, and description about this policy affected by bounded rationality and opportunism from stakeholders to the policy. Therefore, the perception, assumption, and description will affect stakeholder behavior to the implemented policy.

The success in implementation of performance-based budgeting also affected by factors included in the principles of public policy implementation. Consistency over perception, assumption, and description is important thing to assure that there will no deviation or abuse from upper level to the lower level. Luthans (2005) explained about consistency of policy that divided into two types, internal consistency and goal (external) consistency. It is called by internal consistency due to it includes consistency to the goal, focus, procedure, and implementation conducted based on performance evaluation established since early. While external consistency includes clear direction from the policy itself, thus stakeholders will understand the goal that want to be achieved by government consistently. Synergy and integration among policies to make it not overlapping, contradicting, or confusing are coherence of public policy.

It is proven in Pradnya's (2020) research that the budget has not been fully realized and can even harm the entire community. Generally, between the created formulation and environment should be integrated to achieve the success of created policy, in this case of performance-based budgeting.

Firmansyah, et. al. (2017) also affirmed that in budgeting, the external factor from everyone of budgeting actor is stronger and more dominant than the internal factor. The external factors are pressure from environment, superior intervention, or budget participation that very strongly occurred during this time in affecting budgeting process. Meanwhile, the internal factors include competence, skills, regulation understanding, and so forth are not strongly affecting budgeting process. It indicates that the resulted budget is not really represents government performance or fulfillment in people needs. Therefore, budget policy is more like planned activities involving mass psychological techniques and skilled dramaturgy techniques.

\section{METHODOLOGY}

This research was conducted in one of the provinces in Indonesia, let's call it Melati Province (disguised). The author collected data through in-depth interviews with informants from two SKPDs. The author has selected two key informants who are officials in the field of budgeting. This paper is in critical paradigm. Basic assumption in critical paradigm related to the belief that there is latent power in the public or society that very powerful to control process of people communication. It means that critical paradigm sees the "reality" behind control of people communication. The question is who have that control power? Why he or she can control? What is the interest? By those questions, it is seen that critical theory views that there is domination and marginalization process to certain group in the whole process of people communication. Thus, dissemination process and mass communication activities also heavily affected by political economic structure from the related people. 
Although there are various types of critical tradition, all of them have three main special features as mentioned by Littlejohn and Foss (2011: 68-69) as follow:

"First, this tradition attempts to understand system that considered as the right system, structure of power, and belief - or ideology - that dominating society or community, with certain perspective where the interests presented by the structure of power. Second, the experts of critical theory, in general, are interested in revealing suppressing social condition and set of power in order to promote emancipation or people with more freedom and more prosperous. Understanding suppression in removing illusion of ideology and acted to cope with suppression strengths. The third critical theory is creating awareness in order to relate theory and action. Those theories are normative and acted to gain or achieve change in conditions affect society."

This is the foundation for the selection of critical paradigm to achieve goal in this paper. In this paradigm, one of thoughts becomes basic of analysis is Habermas's thought called as critical theory of hermeneutic. Why is his thought selected? It is because Habermas's theory of communicative action considered as very suitable to the phenomena in this paper.

\section{Habermas and his Critical Theory}

Jurgen Habermas stated that critical theory is not scientific theory that commonly known around our academician and society, rather it is a methodology stands on the dialectic tension between philosophy and sociology. Critical theory is not only limited to the objective factors that commonly adopted by positivism; however, it attempts to go through social reality as sociological fact to find transcendental condition over empirical data. Therefore, it can be stated that critical theory is ideological criticism.

Critical theory by Habermas, specifically, updates the critical theory by Frankfurt School that has dead end. Habermas formulates the concerns in a new way to conduct structural changes radically, without leaving concerns from the earlier theorists. Those changes cannot be imposed revolutionary through "violence way", because it will only replace old suppression with new suppression. Meanwhile, people absolutely will not change if the member of community only waiting for the change without doing anything. From here, Habermas's idea was born, which is social transformation needs to be fought through "emancipatory dialogs". According to him, realizing community interacted in communication situation that free from suppression power only can be conducted through "communication" and not through "domination".

This perspective of Habermas, then, is interesting to be studied further, moreover, many countries keep conducting human development including Indonesia. Contradiction caused by the changes of socio-cultural result not only in the development or advance but also unstable or unbalance development. Social injustice is not only fact that attempted to be improved, rather it is also a condition preserved in disguise and becomes a climate. This kind of situation not only needs technical-practical treatment, but also needs to accept about critical theory in 
order to break cover of ideology trapping knowledge from community members about the social reality (Hardiman, 1990). In such situation, ideological criticism is necessary, either to the knowledge describing the social factor to the society or community itself.

\section{Analysis Data and Procedure}

Data in this paper obtained from one key informant and two additional informants, government apparatus at section of finance and budgeting in Regional Government Work Unit (SKPD). Information collection conducted through unstructured interview. The result of interview then made as script and then analyzed based on hermeneutic modus.

Hermeneutic is philosophical base and data analysis modus. As philosophical base, hermeneutic focused on human understanding towards interpretivism, while as analysis modus, hermeneutic related to the definition of textual data. Hermeneutic, mainly related to the meaning of analogical text. Idea of a hermeneutic circle is dialectic between text understanding as a whole and interpretation of its parts, in which the description expected to create meaning with guidance by predicted explanation.

Comstock (1980) explained that critical research started from a study to subject's world to understand their living, especially about social rules, values, and certain motivations that encourage them to behave. Social action dominated by world social institution models, thus what they do is realization from their understanding to that world. Critical research, therefore, needs in-depth understanding to the behavior, values, and motivations of subject (people). Because of that, it can be stated that the second step from critical research is hermeneutic which means that the researcher sees and feels through dialog with participants to understand their social reality. The result of dialog will result action plan to solve social problems faced together.

\section{RESULT AND DISCUSSIONS}

Budgeting with performance approach emphasizes on value for money concept and monitoring over output performance. Sustainable performance assessment in this system will result in feedback, thus it can be conducted by sustainable improvement to achieve better result in the future. Ironically, the implementation of performance-based budgeting in regional government area is not as good as its concept. Paradigm towards budgeting actors that see everything is so easy still strongly perceived in the government implementation.

\section{Performance-Based Budgeting: Merely Formality}

History where a paradigm born as well as factor of condition and context from the paradigm that successfully implemented in a country mostly is strongly different with condition where the paradigm implemented and will be implemented in other country. Phenomena that mostly occurred is paradigm that successfully implemented in certain region is unable to solve bureaucratic 
problems in other region, even that paradigm only adds problem complexity in that bureaucracy or government.

Finance Education and Training Agency (BPPK- Badan Pendidikan dan Pelatihan Keuangan) Department of Finance (2008) stated that Indonesian government has conducted Performance-Based Budgeting, however it is still not fully implemented and inconsistent. Many regional governments have implemented performance-based budgeting; however, it is still the frame, not on its process. It is stated by Mr. Joko (pseudonym), the key informant in this paper:

"We conduct budgeting at Regional Government Work Unit (SKPD) in few steps, started from planning to the establishment of annual budget. Usually, we make planning for some rupiahs with the detail for many work programs. However, after it goes through many processes, finally we change it by adjusting program and established budget."

The implementation of budgeting in Indonesia, today, is still far away from what is expected in New Public Management, including Melati Province. Budgeting still conducted based on political intention that supported by power interference, thus performance-based budgeting system, in plain view, becomes "marginalized or excluded" (not used in budgeting process). The government does not establish budget based on performance that want to be achieved or by seeing work programs made by SKPD; however, the government directly establishes number of certain nominals which then that number allocated to the available work programs. When the established number is not suitable to the needs or programs made by SKPD, then it will be adjusted about fund/budget allocation in each program. Moreover, when the given budget cannot cover all planned programs, then there will be work programs that forced to be excluded from budget plan in related year.

Mr. Ponari (pseudonym) as officer at section of budgeting in one of SKPD also stated that:

"If it talks about budgeting, then we already make it in such a way in order to achieve certain performance target. However, number of budget that "established/agreed" as next year budget in our SKPD is not suitable for the initial plan. Finally, we should remake it and adjust it to what has been established from the upper (the term refers to power holder). We are only planners, whatever the result from the upper, then that what we will implement."

In practice, the government does not conduct comprehensive re-evaluation about work programs; however, the government directly establishes number of budgets for each Regional Government Work Unit (SKPD) in the regional area. Usually, it is caused by political climate that very strongly affects decision making. Legislative as government agent acted as opportunistic in arranging Local Revenue and Expenditure Budget (APBD) (Abdullah dan Asmara, 2006). Power that owned by legislative gives bit looseness for legislative to pressure executive. The higher position of legislative power makes executive has difficulty to refuse legislative 
recommendation in resource allocation, especially allocation gives benefit to legislative. Therefore, budget outcome of public service has distortion and disadvantageous or results in public damage.

Budgeting cannot be merely technical, but also there is political intervention. Battle for power from political elites leads to the various political lobbies in the budgeting process, even many political contaminations in budgeting process conducted openly. In the government regime that full of Corruption, Collusion, and Nepotism, the implementation of whole process aims to conduct financial control only conducted merely for administrative aspect. Therefore, budgeting actors are only oriented to the organization input. When this thing occurred, then, clearly the performance-based budgeting used as budgeting technique useless or cannotbe used as it should be.

It becomes irrelevant in government world, which is performance-based budgeting that been sounded and appears in many regional financial statements not suitable with what been occurred in the backstage. Performance-based budgeting that sounded in the implementation of public sector budget system, in fact, only a mirage. It is seen as performance-based budgeting, but it is not performance-based budgeting. Syarifuddin (2009) has found that construction of government accounting policy is no other than drama or theater show in its definite meaning. It means that many policy phenomena are more conducted intentionally, consciously, and planned to involve all dramatic elements. There is scenario writer, field actor, audience, and absolutely stage for the show.

The other weakness placed on paradigm of budgeting actors in regional government, because although the resulted format is performance-based budgeting, but, in fact, process that conducted in budgeting still uses traditional approach (incremental budget system), which is establishing budget plan by increasing number of budgets with certain percentage based on previous budget or ongoing budget. Mr. Hary (pseudonym) as one of apparatus in section of regional finance stated that:

"We conduct budgeting every year by increasing 15\% from previous year. It is conducted either for regional revenue or expenditure."

Refers to the statement above, budgeting is still incremental, thus analysis towards success and outcome overwork program is not conducted. As the consequence, relevant and logic information for budget allocation in the next year is unavailable. Budget allocation for each unit only based on historical record and not refers to the goal of organization itself.

If it is seen from budgeting format, indeed, regional government has used performance-based budgeting; however, in the budgeting process itself, the budgeting actors still use budgeting traditional system (Rahayu, et al., 2007; Utari, 2009; Puspitasari, 2013; Prastowo, 2014). There are many budgeting aspects made by incremental system and more oriented to the accomplishment of activities and regional financial accountability without paying attention or care about whether the programs/activities are suitable to the goal that want to be achieved and result in value-added to the people welfare. 


\section{The Ignored Needs and Benefits}

The report from Ministry of State Apparatus Empowerment and Bureaucratic Reform (KEMENPAN-RB) in 2016 stated that the implementation of evaluation, many findings that frequently appear are unsuitability between Strategic Plan and National Medium Term Development Plan (RPJMN), inability to define performance, inability in arranging work indicators, and unsuitability between planning and budgeting. Therefore, it can be stated that regional government, in budgeting process, still not fully considers about the performance towards public service. Whereas bureaucratic reform conducted through New Public Management (NPM) by adopting private sector into public sector management aimed to improve government performance.

The other surprising thing is evaluation report from Government Performance Accountability (AKIP) of regional government 2016, it is stated that there is potential of wastefulness for $30 \%$ State Budget Revenue and Expenditure /Local Budget Revenue and Expenditure Budget (APBN/APBD) out of employee expenditure each year, or it is equal to the IDR 292.87 trillion, said by Minister of State Apparatus Empowerment and Bureaucratic Reform (menpan.go.id, 2017). There is wastefulness conducted by regional government each year, and it is enough to show that fulfillment of public service still not fully conducted in the name of people.

Focus or concern from budgeting actors still direct to the activities that will be implemented, and not concerning on work indicators for the outcome that want to be achieved, moreover, for people welfare. According to Mr. Joko:

"Indeed, we admit that budget absorption in regional government still more dominated to the apparatus expenditure. However, we keep trying to conduct improvement to the fulfillment of public service. We conduct it step by step, thus it may need longer time for the whole realization."

Absolutely, it rises a big question about how the perception of regional government towards performance-based budgeting. The change on budgeting rules and format as well as its technique, indeed, is easier to be conducted than changing paradigm about how to think. Changing regional paradigm that has been accustomed with traditional budgeting systems to performance-based budgeting systems is not easy. Lack of communication, integrated computer application system, reward and punishment system, and work ethics become the cause of problems in performance-based budgeting (Widyantoro, 2010).

The other weakness that clearly appears in regional budgeting process is tendency to "spend the budget". Moreover, the ability in spending budget becomes indicator of success in budget realization. It also leads to the implementation that unsuitable to performance-based budgeting concept. Condition that mostly occurred is behavior that always tries to spend budget without paying attention to result and quality of budget utilization, and again, the work indicator becomes ignored.

Performance-based budgeting should refer to the people's needs. Budgeting should be part of information system that serves as reducing opportunism of 
agent, in this case is stakeholders in budgeting process (Eisenhardt, 1989). Sadly, the fact is in the opposite, which is conflict of interest between actors always appear in resource allocation or budgeting process that realized in the budget establishment every year.

Conflict of interest between actors involved in budgeting process makes the right implementation of performance-based budgeting as its goal getting blurred. It is regrettably because there are political motives that make budgeting process becomes unobjective and even has betrayed people's mandate. The existence of conflict of interest is something that cannot be ignored due to all involved parties have their own interest and no more paying attention on the aspect of people needs. It means that conflict of interest from budgeting actors has betrayed public policy due to, as with its principle, regional budgeting is public policy.

\section{CONCLUSION}

\section{Reflection}

Budgeting process that conceptually uses performance-based budgeting is no more appropriate to the process based on reality. Although the budgeting format has been suitable to the performance-based budgeting and refers to the prevailed law regulation, the budgeting system unable to give performance information. It causes difficulty in controlling performance from each regional government. There are many weaknesses in this performance-based budgeting practice such as high political and power interference, minimum apparatus behavior that able to encourage the success of performance-based budgeting implementation, budgeting culture that still far away from budgeting benefit aspect, less control, and so on. Those weaknesses, indeed, need to be reviewed to make improvements for maximum implementation of performance-based budgeting.

Performance-based budgeting is good type of budgeting system. It is proven from many developed countries that been success in the implementation and results in quite significant effect to the fulfillment of public service. However, there are also many other countries that not quite success in the implementation of performance-based budgeting system, especially developing countries, including Indonesia (particularly Melati Province). The term "one size for all”, in fact, cannot be applied, moreover in budgeting system that is quite vital for the development of a country. May be the system is suitable for one country, but not for others.

Indonesia as a country with strong ideology, which is Pancasila, seems to be less suitable in the implementation of performance-based budgeting. Many factors have been outlined in the result and discussion above such as political interference, apparatus behavior, and budgeting culture that led to the weak implementation of this performance-based budgeting. Although the format is seen like performance-based budgeting, in budgeting process, it is still far away from the true concept, thus the performance-based budgeting only as if it is a mirage. Many things should be concerned to make the implementation of performancebased budgeting getting better in the future. One of things that should be really 
concerned is nation ideology that may be different with ideology of New Public Management itself.

\section{Opportunity for Further Research}

The opportunity for further research is the need of empirical and philosophical study about the contradiction between performance-based budgeting ideology and ideology of Indonesia. It becomes quite important to know the unsuitableness between concept and implementation of performance-based budgeting fundamentally. Besides that, it is also necessary to conduct further research that able to study specifically about government organizational culture in regional budgeting by using ethnography, ethnomethodology, or even quantitative method to obtain result and description about regional budgeting culture.

\section{REFERENCES}

Abdullah, Syukriy, dan Asmara, Jhon Andra. 2006. Perilaku Oportunistik Legislatif dalam Penganggaran Daerah. Simposium Nasional Akuntansi 9, Padang.

Barzelay, Michael. 1992. Breaking through Bureaucracy: A New Vision for Managing in Government. Berkeley: University of California Press

Bromley, Daniel W. 1989. Economic Interst and Institution. The Foundation of Public Policy. Oxford Brazil Blackwell

Comstock. (1980). A Method for Critical Research. Washington: Red Feather Institute for Advanced Studies in Sociology

Denhardt, Robert B. dan Janet V. Denhardt. 2000. The New Public Service: Service Rather than Steering. Public Administration Review, 60 (6). https://doi.org/10.1111/0033-3352.00117

Eisenhardt, Kathleen M. 1989. Agency theory: An assessment and review. Academy of Management Review 14(1): 57-74. https://doi.org/10.5465/amr.1989.4279003

Firmansyah, Rizky, Rosidi, dan Abdul Ghofar. 2017. The Effect of Attribution Theory to The Budgetary Slack. Imperial Journal of Interdisiplinary Research, Vol-3, Issue-3, 364-375

Golembiewski, R. T. (2003). Handbook of organizational behavior. USA: Marcel. Dekker, Inc.

Gow, James Lain, dan Caroline Dufour. 2000. Is the New Public Management a Paradigm? Does it Matter? International Review of Administrative Sciences, 66, 573. https://doi.org/10.1177/0020852300664002

Gruening, Gernod. 2001. Origin and theoretical basis of New Public Management. International Public Management Journal, 4, 1-25. https://doi.org/10.1016/S1096-7494(01)00041-1

Hardiman, F. Budi. 1990. Kritik Ideologi: Pertautan Pengetahuan dan Kepentingan. Yogyakarta: Kanisius

Kementerian Pendayagunaan Aparatur Negara dan Reformasi Birokrasi. (online) diaskes di : www.menpan.go.id, pada tanggal 9 April 2017.

Littlejohn, Stephen W \& Karen A. Foss. 2011. Teori Komunikasi, edisi 9. Jakarta: Salemba Humanika 
Luthans, Fred. 2005. Perilaku Organisasi Edisi Sepuluh. Yogyakarta : Penerbit Andi Lynn, Jr, Laurence E. 2006. Public Management: Old and New. New York: Rouledge https://doi.org/10.4324/9780203964774

Osborne, David dan Ted Gaebler. 2003. Reinventing Government (Mewirausahakan Birokrasi): Sepuluh Prinsip untuk Mewujudkan Pemerintahan Wirausaha. Jakarta: PPM

Pradnya, I. M. (2020). Perencanaan dan Partisipasi Penyusunan Anggaran Berperspektif Gender pada Pemerintah Daerah. Public Management and Accounting Review, I(1), 45-58

Puspitasari, Ratna. 2013. Studi Penganggaran Berbasis Kinerja Pada Pemerintah Provinsi Jawa Timur, Jawa Barat, dan DKI Jakarta. Jurnal Jejaring Administrasi Publik. Vol. 5, No.2: 356

Rahayu, Sri, Unti Ludigdo, dan Didiet Affandy. 2007. Studi Fenomenologis terhadap Prose Penyusunan Anggaran Daerah (Bukti Empiris dari Satu Satuan Kerja Perangkat Daerah di Propinsi Jambi). Simposium Nasional Akuntansi X, Universitas Hasanudin. Makasar.

Robinson, Marc, and Last, Duncan. 2009. A Basic Model of Performance-Based Budgeting. International Monetary Fund, Fiscal Afairs Department, USA. https://doi.org/10.5089/9781462320271.005

Shergold, Peter. 1997. The colour purple: perceptions of accountability across the Tasman. Public Administration and Development. Vol. 17, 293-306 https://doi.org/10.1002/(SICI)1099-162X(199708)17:3<293::AIDPAD950>3.0.C0;2-R

Syarifuddin. 2009. Konstruksi Kebijakan Anggaran: Aksentuasi Drama Politik Dan Kekuasaan (Studi Kasus Kabupaten Jembrana Bali). Ekuitas, Vol. 15 No. 3

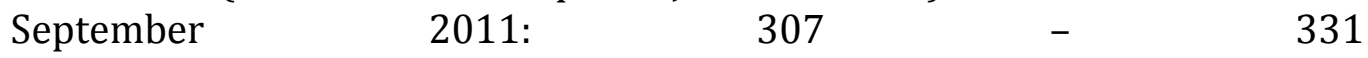
https://doi.org/10.24034/j25485024.y2011.v15.i3.371

Utami, W., \& Machpudin, H. A. (2016). Pengaruh Penerapan Anggaran Berbasis Kinerja Terhadap Akuntabilitas Kinerja Instansi Pemerintah. Jurnal Akuntansi dan Keuangan Unja, 56-68.

Utari, Nuraeni. 2009. Studi Fenomenologis tentang Proses Penyusunan Penganggaran Berbasis Kinerja Pada Pemerintah Kabupaten Temanggung. Tesis, Universitas Diponegoro.

Widyantoro, Ari Eko. 2010. Implementasi Performance Base Budgeting: Sebuah Studi Fenomenologis (Studi Kasus pada Universitas Diponegoro). Tesis, Universitas Diponegoro. 
EQUITY, Vol. 24, No.1, 2021, 1-14

This page is intentionally left blank for fulfillment purposes 